\title{
Liquisolid systems: Evaluation of the influence of formulation variables on the optimum liquid load
}

\author{
Ivana Aleksić*, Teodora Glišić, Sandra Cvijić, Jelena Parojčić \\ University of Belgrade - Faculty of Pharmacy, Department of Pharmaceutical \\ Technology and Cosmetology, Vojvode Stepe 450, 11221 Belgrade, Serbia
}

*Corresponding author: Ivana Aleksić, e-mail: ivana.aleksic@pharmacy.bg.ac.rs

\begin{abstract}
Liquisolid systems represent an emerging approach in the preparation of solid dosage forms with liquid lipophilic drug or poorly water-soluble drug solution/suspension in suitable liquid vehicle. This study addresses the lack of data regarding the compaction behavior of liquisolid systems, with the aim to investigate the influence of liquid load, carrier to coating ratio, carrier type (microcrystalline cellulose vs. spray dried calcium hydrogen phosphate, anhydrous $\left(\right.$ Fujicalin $\left.^{\mathbb{B}}\right)$ ) on flowability and compaction properties of liquisolid systems and to determine the optimum liquid loads. Liquisolid admixtures with Fujicalin ${ }^{\circledR}$ showed notably better flowability than those with microcrystalline cellulose. An increase in carrier to coating ratio led to enhanced flowability of the admixtures. Compacts with Fujicalin ${ }^{\circledR}$ had good mechanical properties up to $24.7 \%$ liquid, while those with microcrystalline cellulose had acceptable mechanical strength up to $16.2 \%$ liquid. Liquisolid systems with Fujicalin ${ }^{\circledR}$ showed similar tabletability profiles as those with microcrystalline cellulose, despite having higher liquid content. The ejection stress values indicated that the addition of lubricant might be needed in the case of liquisolid systems with Fujicalin ${ }^{\circledR}$. Superior properties of Fujicalin ${ }^{\circledR}$ as a carrier for liquisolid tablets were revealed, and dynamic compaction analysis was found to be a valuable tool for the assessment of compaction behavior of liquisolid systems.
\end{abstract}

Keywords: liquisolid compacts, tabletability, dynamic compaction analysis, Fujicalin ${ }^{\circledR}$, microcrystalline cellulose

doi.org/10.5937/arhfarm72-33130 


\section{Introduction}

Liquisolid (LS) systems were introduced in the late 1990s as a novel approach to formulate solid dosage forms, i.e. tablets or capsules, with liquid medications. The term liquid medication refers to liquid lipophilic drug or drug solution/suspension in nonvolatile, hydrophilic liquid vehicle (1). Spireas (2) proposed this technology as a promising alternative to numerous, but complex and costly approaches that are commonly employed to improve bioavailability of poorly soluble drugs. Moreover, it was shown that this relatively simple technique can be applied to achieve both immediate and sustained release. However, this technology has gained increased research interest more recently, and during the last decade enhanced dissolution from LS systems has been reported for various poorly soluble drugs (3-8). Furthermore, recently reported in vivo studies showed improved bioavailability in the case of LS systems with different poorly soluble drugs (9$15)$.

Enhanced dissolution rate from LS systems has been attributed to the increased drug surface area, improved wetting properties or enhanced aqueous solubility of the drug that is suspended or dissolved in suitable hydrophilic liquid, e.g. macrogols, propylene glycol, polysorbates (16). In order to prepare non-adherent LS powder, excipients with highly porous structure are used. These excipients include a "carrier" used to absorb the liquid in its inner pores and "coating" material which possesses fine porous particles (preferably $10 \mathrm{~nm}$ to $5 \mu \mathrm{m}$ in diameter) able to coat carrier particles and thus keep the surface of these particles dry, by adsorbing any excess liquid from the surface of carrier particles (2). Microcrystalline cellulose is a commonly used carrier, while colloidal silica is the most commonly used coating material.

With the aim of ensuring the application of the LS concept on an industrial scale, Spireas proposed the formulation approach with a mathematical model to determine the maximum liquid content resulting in acceptably flowing and, simultaneously, compressible powder. Namely, at the given carrier to coating ratio $(\mathrm{R}=$ quantity of carrier (Q)/quantity of coating material (q)) only a certain amount of the liquid can be retained while maintaining good flow and compaction properties. He proposed a specific parameter, "angle of slide", for the evaluation of flowability with the limiting value for the acceptable flow of $33^{\circ}(17)$, but a common method based on the measuring of the powder flow rate was also considered (2). LS admixtures showing good flowability may have poor compaction properties, i.e. compacts with unacceptable mechanical properties can be obtained and/or liquid can be squeezed out during compression, resulting in the loss of the active ingredient. Therefore, "liquisolid compressibility test" was developed and described by the author as a simple and accurate method to evaluate compaction properties. A specific parameter named "pactisity" was proposed, representing the resistance to crushing of a one-gram tablet that is compressed under the force required to achieve maximum tablet resistance to crushing. The LS system can be considered acceptably compressible if it can be compressed to a pactisity greater than or equal to 20 $\mathrm{kg} / \mathrm{g}$, without any observed liquid squeezed out during compression (2). 
According to these criteria for a given R value "flowable liquid load factor" ( $\left.{ }^{\Phi} \mathrm{L}_{\mathrm{f}}\right)$ and "compressible liquid load factor" ( ${ }^{\Psi} \mathrm{Lf}_{\mathrm{f}}$ ) can be determined, where liquid load factor $\left(\mathrm{L}_{\mathrm{f}}\right)$ corresponds to the ratio of the amount of liquid, $\mathrm{W}(\mathrm{g})$ over the quantity of carrier, $\mathrm{Q}$ $(\mathrm{g})$. Finally, the optimum load factor $\left(\mathrm{L}_{\mathrm{o}}\right)$ is defined by the following rule:

$$
\begin{aligned}
& \mathrm{L}_{\mathrm{o}}={ }^{\Phi} \mathrm{L}_{\mathrm{f}} \text { when }{ }^{\Phi} \mathrm{L}_{\mathrm{f}}<{ }^{\Psi} \mathrm{L}_{\mathrm{f}} \\
& \mathrm{L}_{\mathrm{o}}={ }^{\Psi} \mathrm{L}_{\mathrm{f}} \text { when }{ }^{\Phi} \mathrm{L}_{\mathrm{f}}>{ }^{\Psi} \mathrm{L}_{\mathrm{f}}
\end{aligned}
$$

For the industrial application of LS technology in tablet production it is of outmost importance to identify the factors affecting both flowability and compaction properties. The influence of different formulation variables, including the carrier and coating material type, the amount and type of liquid phase, the amount and type of viscosity increasing agent, and carrier to coating ratio, on flow properties and flowable liquid load of LS systems has been intensively investigated over the past years $(9,10,18-21)$. For the application of this technology in tablet production not only good flowability, but also acceptable compaction properties have to be ensured. However, studies addressing the mechanical properties of LS tablets are rather limited, and most of them are actually focused on the influence of formulation factors on dissolution behavior and flowability of LS systems, with a report on tablet resistance to crushing and friability (22-25). Published papers reporting more comprehensive investigation into the compaction properties of LS systems are scarce (26) and include our previous study (27).

With a view to addressing this issue, in the present study the optimum liquid loads at different carrier to coating ratios were assessed, considering that requirements for both good flowability and acceptable compaction properties had to be met. Two different carriers, microcrystalline cellulose and Fujicalin ${ }^{\circledR}$, were used and compared in terms of their liquid retention potential. Fujicalin ${ }^{\circledR}$ is a relatively new directly compressible excipient, and it is calcium hydrogen phosphate, anhydrous, which, as a spray-dried product, has smooth, spherical, and highly porous particles. Due to the high specific surface area, it has also been suggested as a suitable excipient for LS systems (28). The goal of this study was also to investigate the compaction behavior of LS systems more thoroughly by means of dynamic compaction analysis, which has not been reported in literature so far.

\section{Experimental}

\section{Materials}

Microcrystalline cellulose (MCC, Vivapur ${ }^{\circledR}$ type 101, JRS Pharma, Germany) and spray dried calcium hydrogen phosphate, anhydrous (Fujicalin $\left.{ }^{\circledR}\right)$, kindly donated by Fuji Chemical Industry Co, Ltd., Japan, were used as carriers for preparation of LS systems. Colloidal silicon dioxide (Aerosil ${ }^{\circledR}$ 200, Evonik Industries AG, Germany) was used as coating material and polyethylene glycol 400 (PEG 400, Sigma-Aldrich, Germany) as liquid phase. 


\section{Methods}

\section{Preparation of liquisolid admixtures}

LS admixtures with five different carrier to coating ratios and liquid loads in the range of 0.12 to 0.48 were prepared, giving a total of 29 admixtures with MCC and 31 admixtures with Fujicalin ${ }^{\circledR}$. The corresponding $\mathrm{R}$ and $\mathrm{Lf}_{\mathrm{f}}$ values of the LS powders prepared are presented in Table I. LS powders were prepared according to the mixing procedure described by Spireas (2), by using a mortar and pestle.

Table I Composition of the investigated liquisolid admixtures.

Tabela I Sastav ispitivanih tečno-čvrstih smeša.

\begin{tabular}{|c|c|c|c|}
\hline Liquisolid admixture $^{a}$ & $\mathbf{R}$ & $\mathbf{L}_{\mathbf{f}}$ & PEG 400 (\%) \\
\hline $\mathrm{M} 1 / \mathrm{F} 1$ & 5 & 0.12 & 9.1 \\
\hline $\mathrm{M} 2$ / F2 & 5 & 0.18 & 13.0 \\
\hline M3 & 5 & 0.20 & 14.3 \\
\hline M4 / F4 & 5 & 0.24 & 16.7 \\
\hline M5 / F5 & 5 & 0.30 & 20.0 \\
\hline M6 / F6 & 5 & 0.36 & 23.1 \\
\hline M7 / F7 & 5 & 0.48 & 28.6 \\
\hline M8 / F8 & 10 & 0.12 & 9.8 \\
\hline M9 / F9 & 10 & 0.18 & 14.1 \\
\hline M10 & 10 & 0.20 & 15.4 \\
\hline M11 / F11 & 10 & 0.24 & 17.9 \\
\hline M12 / F12 & 10 & 0.30 & 21.4 \\
\hline M13 / F13 & 10 & 0.36 & 24.7 \\
\hline M14 / F14 & 10 & 0.48 & 30.4 \\
\hline M15 / F15 & 15 & 0.12 & 10.1 \\
\hline M16 / F16 & 15 & 0.18 & 14.4 \\
\hline M17 / F17 & 15 & 0.20 & 15.8 \\
\hline M18 / F18 & 15 & 0.24 & 18.4 \\
\hline M19 / F19 & 15 & 0.30 & 21.9 \\
\hline M20 / F20 & 15 & 0.36 & 25.2 \\
\hline M21 / F21 & 15 & 0.48 & 31.0 \\
\hline $\mathrm{M} 22$ / F22 & 20 & 0.12 & 10.3 \\
\hline $\mathrm{M} 23$ / F23 & 20 & 0.18 & 14.6 \\
\hline M24 & 20 & 0.20 & 16.0 \\
\hline M25 / F25 & 20 & 0.24 & 18.6 \\
\hline F26 & 20 & 0.30 & 22.2 \\
\hline F27 & 20 & 0.36 & 25.5 \\
\hline F28 & 20 & 0.48 & 31.4 \\
\hline M29 / F29 & 30 & 0.12 & 10.4 \\
\hline M30 / F30 & 30 & 0.18 & 14.8 \\
\hline
\end{tabular}




\begin{tabular}{|c|c|c|c|}
\hline Liquisolid admixture $^{\mathrm{a}}$ & R & Lf & PEG 400 (\%) \\
\hline M31 & 30 & 0.20 & 16.2 \\
\hline M32 / F32 & 30 & 0.24 & 18.8 \\
\hline F33 & 30 & 0.30 & 22.5 \\
\hline F34 & 30 & 0.36 & 25.8 \\
\hline F35 & 30 & 0.48 & 31.7 \\
\hline
\end{tabular}

${ }^{\mathrm{a}} \mathrm{M} 1-\mathrm{M} 32$ are admixtures with MCC, and F1-F35 are admixtures with Fujicalin ${ }^{\circledR}$ as a carrier.

\section{Liquisolid admixture flowability}

Powder flow rate and Carr index value were determined to assess the flowability of LS admixtures. All analyses were performed on samples of $20 \mathrm{~g}$. Erweka flowmeter type GDT (Erweka GmbH, Heusenstamm, Germany) was used to determine the powder flow rate. A graduated cylinder and volumeter STAV 2003 (J. Engelsmann AG, Ludwigshafen, Germany) were used to determine the bulk and tapped (1250 taps) densities. The obtained density values were used to calculate the Carr index.

All determinations were performed in triplicates, and the results are expressed as mean values.

\section{Compression of liquisolid powders}

LS powders were compressed on an eccentric tablet machine EKO Korsch (Korsch AG, Germany). Flat-faced punches with $13 \mathrm{~mm}$ diameter were used, and compression conditions were adjusted for each admixture in order to achieve maximum compact resistance to crushing. Compact weight was set to $400 \mathrm{mg}$.

\section{Compact resistance to crushing}

Compact crushing force and diameter were determined using the tablet hardness tester Erweka TBH 125D (Erweka GmbH, Germany). Compact thickness was measured using a caliper. Measurements were performed on at least ten samples, and the results are expressed as mean values.

These results were used to calculate pactisity according to the following equation (2):

$$
\Omega=\frac{S_{c}}{w_{t}}
$$

where $S_{c}$ represents compact crushing strength, i.e. crushing force expressed in kilograms, and $\mathrm{w}_{\mathrm{t}}$ is the compact weight in grams.

Tensile strength was calculated using the equation developed by Fell and Newton (29):

$$
\sigma=\frac{2 \cdot F}{\pi \cdot d \cdot t}
$$

where $\mathrm{F}$ is the compact crushing force, $\mathrm{d}$ is the compact diameter and $\mathrm{t}$ is the compact thickness. 


\section{Dynamic compaction analysis}

A single punch instrumented tablet press (GTP D series, Gamlen Tableting Ltd, UK) with supporting software (Gamlen Tablet Press Controller Version 3.26) was used for the dynamic compaction analysis of the LS systems. Compacts $(75 \mathrm{mg})$ were compressed under six different compression loads in the range of 250 to $500 \mathrm{~kg}$, with the increment of $50 \mathrm{~kg}$. Flat faced punches with a diameter of $6 \mathrm{~mm}$ were used, and compaction speed was $60 \mathrm{~mm} / \mathrm{min}$. The obtained force-displacement curves were used to calculate: the net work of compression, detachment stress, ejection stress.

Net work of compression, as an indicator of material compressibility, was calculated as the difference between the total work of compression and the work of elastic deformation, which were determined as the area under the force-displacement curve during compression and decompression phase, respectively. The area under the curve was estimated by the trapezoidal rule.

Detachment stress, as a measure of friction between the lower punch and compact during detachment, was determined using the following equation:

$$
D S=\frac{F}{r^{2} \pi}
$$

where $\mathrm{F}$ is the peak force during detachment phase and $\mathrm{r}$ is the compact radius.

Ejection stress, as a measure of friction between the die and compact during ejection of the compact, was determined using the following equation:

$$
E S=\frac{F}{\pi d t}
$$

where $\mathrm{F}$ represents the peak force during ejection phase, $\mathrm{d}$ is the compact diameter and $t$ is the compact thickness.

Elastic recovery was calculated according to the following equation (30):

$$
E R=\frac{t_{1}-t_{0}}{t_{0}} \cdot 100
$$

where $t_{0}$ and $t_{1}$ represent compact thickness under maximum compression pressure inside the die and $24 \mathrm{~h}$ after compression outside the die, respectively.

Compact crushing force was measured for the compacts obtained under different compression pressures, and these values were used to calculate tensile strength according to the equation (2). Tabletability profiles were obtained by plotting compact tensile strength versus compression pressure applied.

All measurements were performed on at least three samples and the results are presented as the mean values. 


\section{Estimation of the optimum liquid load}

In order to estimate the optimum liquid load for the investigated LS systems, both flowable and compressible liquid load factors, i.e. liquid loads resulting in both acceptable flowability and acceptable compaction properties, were determined. The lower of these two values was considered the optimum liquid load. LS admixtures that showed a Carr index value lower than $21 \%$, and consistent flow without any blockages, were considered to have an acceptable flowability. LS systems resulting in compacts that showed a pactisity value greater than or equal to $20 \mathrm{~kg} / \mathrm{g}$ and/or tensile strength higher than or equal to $1 \mathrm{MPa}$, were considered to have acceptable compaction properties.

\section{Results and discussion}

\section{Flowability of liquisolid admixtures}

Poor flowability of liquid-powder admixtures was recognized to potentially hinder its wider application in solid dosage forms production, and therefore a formulation approach that will ensure good processability of LS powders has been developed by Spireas and co-workers $(17,1)$. This approach considered the application of a specific flowability testing method - angle of slide (17). However, this method is not widely used in powder flow characterisation and subsequently assessment of the powder flow rate has been proposed for the determination of flowable liquid load factor (2). The LS flowability test is a titration-like procedure that considers the addition of increasing amounts of liquid phase to the powder system (carrier and coating material) in order to determine the maximum liquid load at which flowability is retained within the pre-selected limits of acceptable flowability. This means that a slightly higher liquid content than the maximum liquid load would lead to unacceptable flowability of the LS powder.

The values of powder flow rate are highly dependent on the testing conditions and equipment used, and the limits of acceptable flowability should be defined with regards to the specific requirements of the equipment used for subsequent capsule filling or tablet compression. Therefore, in the present study two most commonly used methods for the estimation of powder flowability, the powder flow rate and Carr index, were used to assess flow properties of LS powders.

The results obtained are presented in Figures 1 and 2. According to the powder flow rate values, an enhancement in flowability can be observed with an increase in $\mathrm{R}$ value, i.e. with a decrease in coating material content. This trend is evident in the case of both carriers, but is supported by the Carr index values only in the case of LS systems with Fujicalin $^{\circledR}$, while in the case of MCC LS admixtures Carr index values were less affected by carrier to coating ratio. The observed decrease in flowability at a higher content of coating material (lower $\mathrm{R}$ values) can be explained by the presence of fine particles of coating material in excess, not being attached to the surface of carrier particles, that contribute to cohesivity of LS powder (21). Considering the influence of liquid load, the flowability of LS admixtures with Fujicalin ${ }^{\circledR}$ was found to increase with an increase in liquid content. Similar results were reported by Hentzschel and coworkers (31) and were 
attributed to the highly porous structure and high specific surface area of this carrier, allowing the absorption of high amount of liquid that leads to an increase in the weight of the individual particles followed by enhanced flowability. Carr index values obtained for these admixtures ranged between 7 and 20, which is considered to be excellent to fair flowability (32).
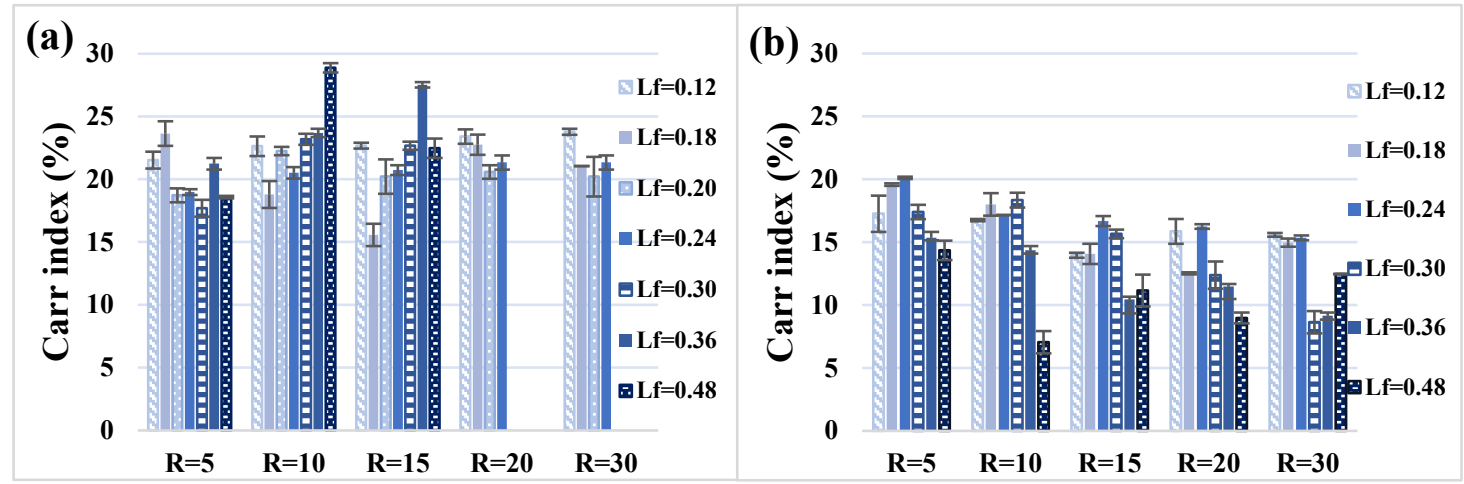

Figure 1. Carr index values of liquisolid admixtures with microcrystalline cellulose (a) and Fujicalin ${ }^{\circledR}$ (b).

Slika 1. Vrednosti Karovog indeksa tečno-čvrstih smeša sa mikrokristalnom celulozom (a) i Fujicalin ${ }^{\circledR}$-om (b).
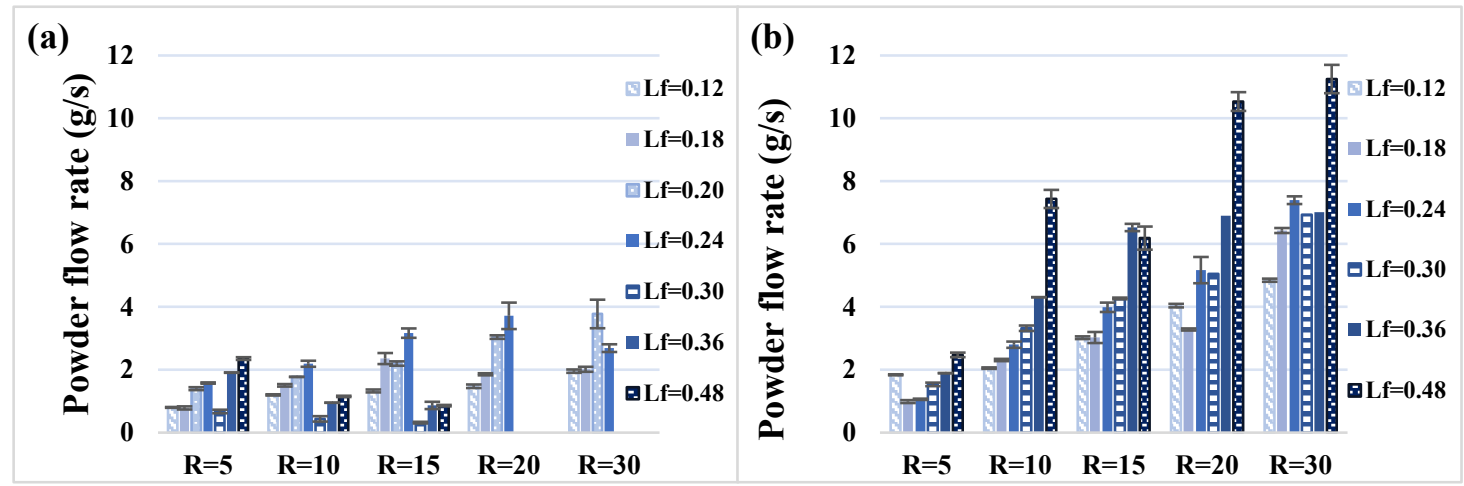

Figure 2. Powder flow rate of liquisolid admixtures with microcrystalline cellulose (a) and Fujicalin ${ }^{\circledR}$ (b).

Slika 2. Protočnost tečno-čvrstih smeša sa mikrokristalnom celulozom (a) i Fujicalin ${ }^{\circledR}$-om (b).

On the other hand, an increase in liquid content led to an improvement in the flow properties of admixtures with MCC, but only up to $\mathrm{L}_{\mathrm{f}}=0.24$, i.e. approximately $16.5-$ $18.5 \%$ liquid content. Further increase in liquid content led to decrease in flowability, similar to other literature reports $(18,31)$. This can be related to the oversaturation of carrier and coating material with liquid, and thus the formation of a more cohesive 
powder. Carr index values obtained for LS admixtures with MCC were in the range of 15 to 29 , representing fair to poor flowability (32).

Both flowability testing methods indicated considerably better flow properties of LS admixtures with Fujicalin ${ }^{\circledR}$ in comparison to those with MCC at the same liquid load. This finding is in accordance with literature data, and could be attributed to the highly spherical shape of Fujicalin ${ }^{\circledR}$ particles and its much higher specific surface area in comparison to MCC, $32 \mathrm{~m}^{2} / \mathrm{g}$ for Fujicalin ${ }^{\circledR}$ vs. $1 \mathrm{~m}^{2} / \mathrm{g}$ for MCC, and thus higher liquid adsorption capacity (31).

\section{Compaction properties of liquisolid admixtures}

Mechanical properties of LS compacts were estimated by calculating two parameters: (i) pactisity, as a specific parameter proposed for LS systems (2), and (ii) tensile strength, as a commonly used parameter to quantify tablet mechanical strength. The results obtained are presented in Figure 3. Neither of the investigated LS systems with Fujicalin ${ }^{\circledR}$ could be considered as acceptably compressible according to the criteria defined by Spireas, since all pactisity values obtained were below $20 \mathrm{~kg} / \mathrm{g}$. LS systems with MCC were found to have pactisity values equal or higher than $20 \mathrm{~kg} / \mathrm{g}$ at liquid load factors up to 0.18 or 0.20 , depending on the $\mathrm{R}$ value. At the lowest liquid load $\left(\mathrm{L}_{\mathrm{f}}=0.12\right)$, compacts with MCC showed considerably higher pactisity and tensile strength values in comparison with those with Fujicalin ${ }^{\circledR}$. MCC is well known as a diluent that has good binding properties and that deforms dominantly plastically during compression, resulting in an excellent mechanical strength of tablets (33). This might be the explanation for its superior mechanical properties at a very low liquid content. However, an increase in liquid load resulted in a pronounced decrease in both tensile strength and pactisity, demonstrated by steep curves in Figure 3. A similar process was observed by Hentzschel and coworkers (31), who found out that good mechanical properties of LS tablets containing $\mathrm{MCC}$ as a carrier can be prepared with up to $8 \%$ tocopherol acetate as liquid drug. At $\mathrm{L}_{\mathrm{f}}$ values higher than 0.24 (17.9-18.8\% liquid content) compacts with sufficient mechanical strength to withstand handling could not be formed, with the exception of compacts with $\mathrm{R}=5$, i.e. with the highest content of coating material. A higher content of coating material allowed the adsorption of excess liquid to some extent (up to $\mathrm{L}_{\mathrm{f}}=0.36$ ), but the compacts formed had very low tensile strength, not higher than $0.5 \mathrm{MPa}$. On the other hand, LS compacts with Fujicalin ${ }^{\circledR}$ were found to have tensile strength in the range of 1 to $2 \mathrm{MPa}$ up to $\mathrm{L}_{\mathrm{f}}$ values of 0.36 or 0.30 (depending on the carrier to coating ratio), which can be regarded as an acceptable mechanical strength (34). Furthermore, the increase in liquid content led to a more gradual decrease in compact tensile strength in comparison to LS systems with MCC. These differences between the two carriers can be ascribed to the considerably higher specific surface area of Fujicalin ${ }^{\circledR}$ and fragmentation as a dominant deformation mechanism, and thus the formation of new contact areas during the compression of this excipients which contributes to the lower influence of liquid on its tableting properties (31). 

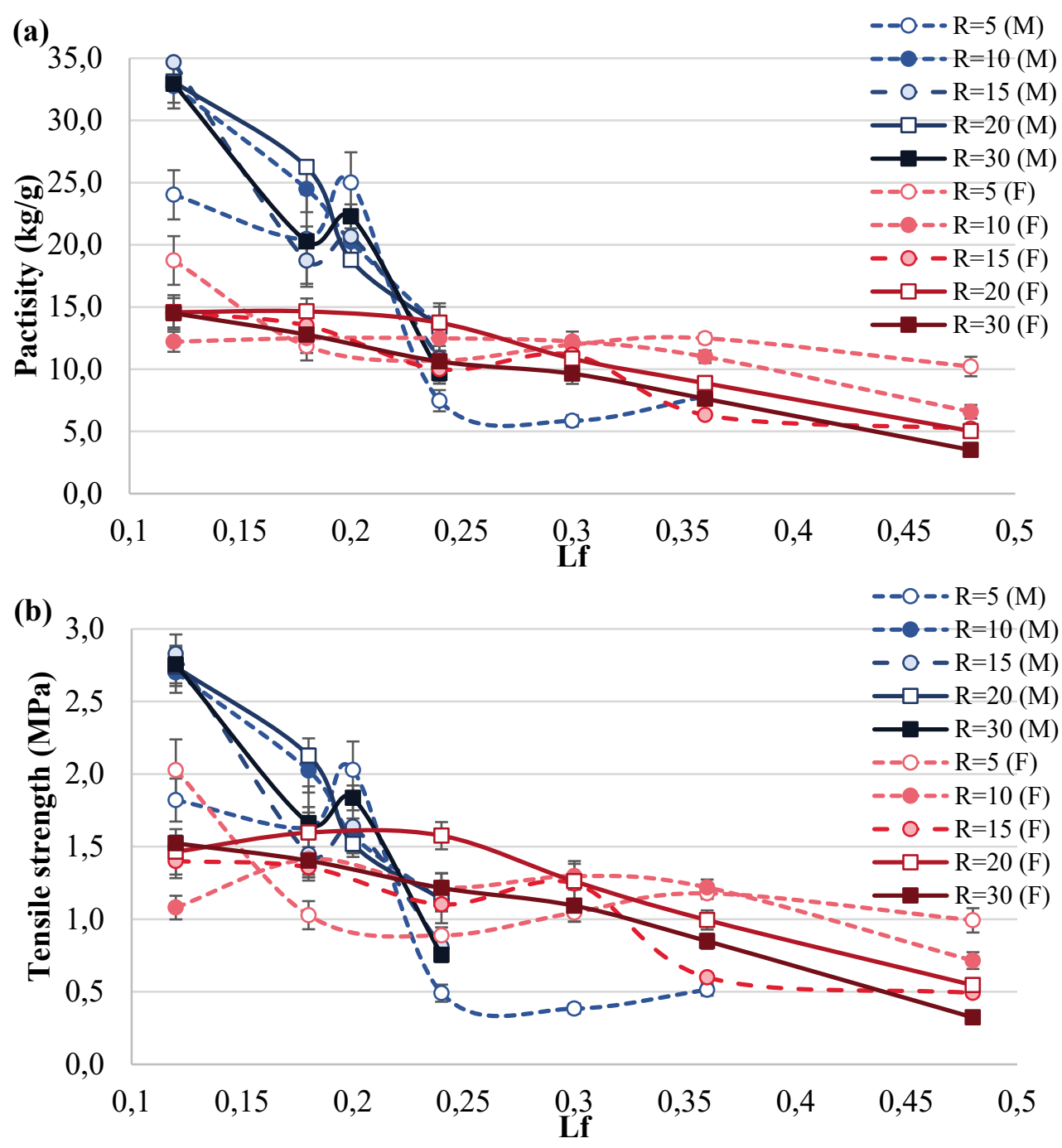

Figure 3. Pactisity (a) and tensile strength (b) of liquisolid admixtures with microcrystalline cellulose (blue curves) and Fujicalin ${ }^{\circledR}$ (red curves).

Slika 3. Pactisity (a) i zatezna čvrstina (b) tečno-čvrstih smeša sa mikrokristalnom celulozom (plave krive) i Fujicalin ${ }^{\circledR}$-om (crvene krive).

For both carriers and each of the investigated carrier to coating ratios, optimum liquid loads were determined with regards to the predefined criteria and these admixtures were selected for dynamic compaction analysis. The results obtained are presented in Figures 4 and 5. Tabletability profiles (tensile strength vs. compression pressure) obtained for LS systems confirmed good mechanical properties of the LS compacts with both carriers, with tensile strength values ranging from 1.5 to $2.5 \mathrm{MPa}$. 

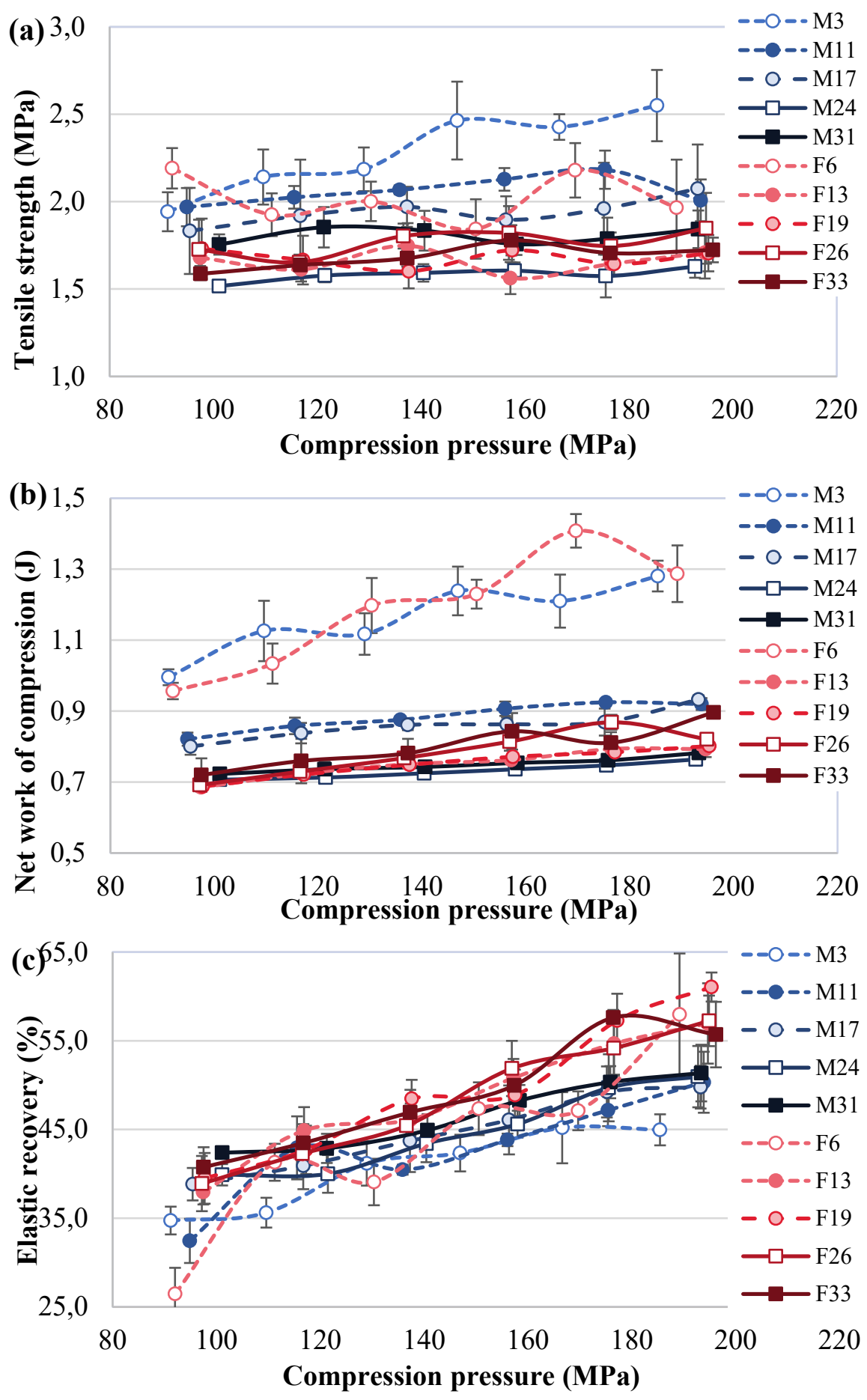

Figure 4. Tensile strength (a), net work of compression (b) and elastic recovery (c) of liquisolid systems compressed under different compression pressures.

Slika 4. Zatezna čvrstina (a), neto rad kompresije (b) i elastični oporavak (c) tečnočvrstih sistema komprimovanih pri različitim pritiscima kompresije. 

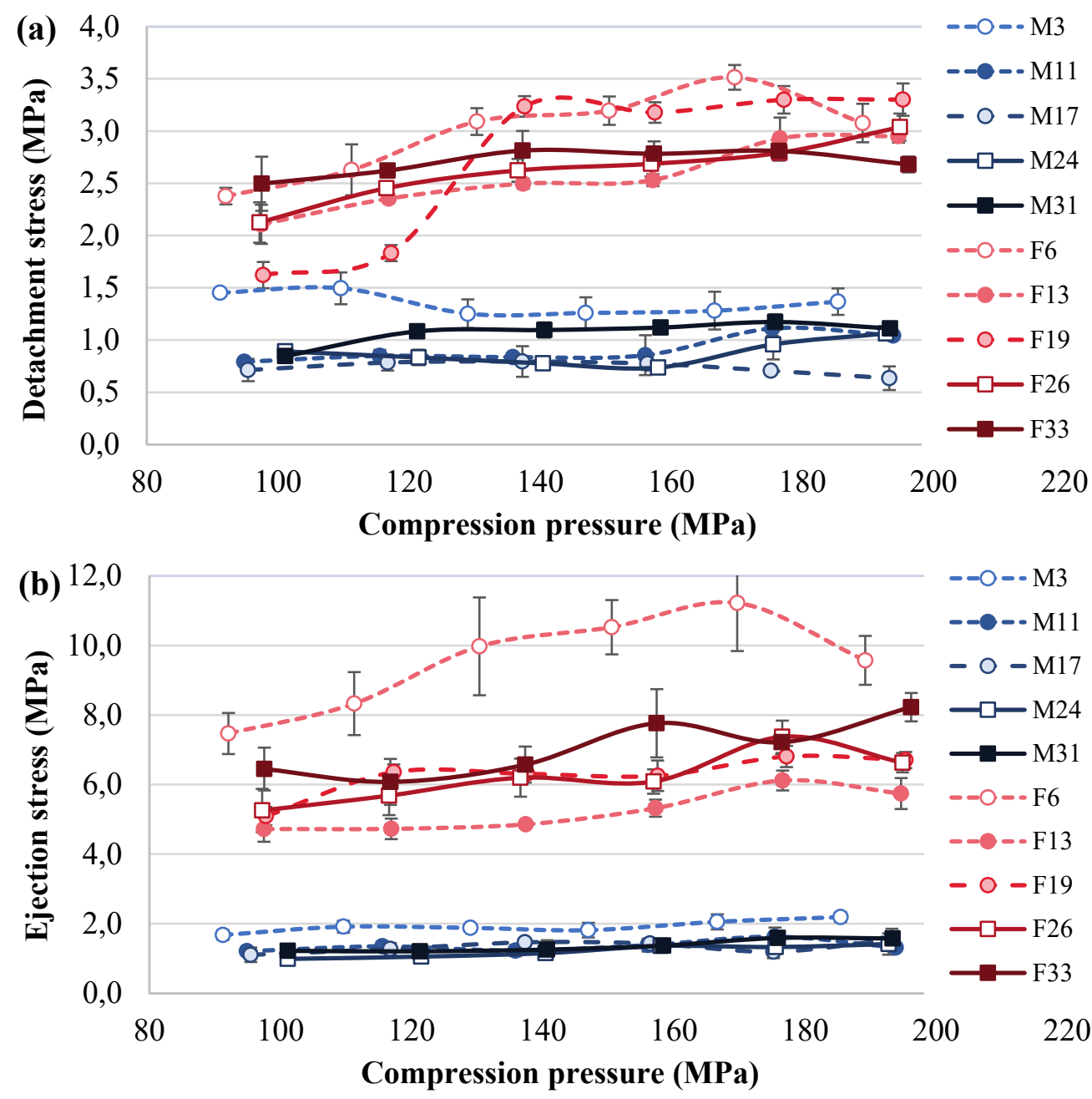

Figure 5. Detachment stress (a) and ejection stress (b) of liquisolid systems compressed under different compression pressures.

Slika 5. Pritisak pri odvajanju (a) i pri izbacivanju (b) tečno-čvrstih sistema komprimovanih pri različitim pritiscima kompresije.

Interestingly, the influence of compression pressure on tensile strength of the prepared compacts was negligible in the case of both carriers, indicating a robust compaction process. It is important to emphasize that LS systems with Fujicalin ${ }^{\circledR}$ showed similar tabletability as those with $\mathrm{MCC}$, despite having a higher liquid content $\left(\mathrm{L}_{\mathrm{o}}=0.3\right.$ -0.36 for Fujicalin ${ }^{\circledR}$ vs. $L_{o}=0.2-0.24$ for MCC). Net work of compression and elastic recovery of the LS systems prepared with two different carriers was found to be comparable, indicating similar compressibility of the investigated admixtures. Neither the $\mathrm{R}$ value nor the compression pressure were found to have a pronounced influence on the net work of compression. The admixtures with lowest R values (M3 and F6), for which somewhat higher values of net work of compression were obtained, were an exception. A larger net work of compression is commonly associated with better compressibility of 
the material, since it is regarded principally as the work consumed on plastic deformation with or without fragmentation. However, it also includes the work needed to overcome die wall friction and particle-to particle interactions (35). It can be observed in Figure 5 that M3 and F6 admixtures showed poorer lubricating properties, demonstrated by higher detachment and ejection stress, and thus somewhat higher values of net work of compression could be attributed to these phenomena, rather than to a higher degree of plastic deformation. Elastic recovery values were found to increase with the increase in compression pressure, indicating that high compression pressures could lead to tablet defects such as capping and lamination.

Detachment and ejection stress are recommended as parameters that might help in avoiding sticking, picking, capping and lamination issues. Ejection stress values lower than $3 \mathrm{MPa}$ are considered to be favorable, and values up to $5 \mathrm{MPa}$ may be acceptable for tablets that will not be subjected to high mechanical stress (36). The results presented in Figure 5 showed good lubricating properties of LS admixtures with MCC, with a negligible influence of compression pressure on detachment and ejection stress values. LS admixtures with Fujicalin ${ }^{\circledR}$ had considerably higher values of both parameters and showed more noticeable differences between formulation with different $\mathrm{R}$ values in comparison with MCC admixtures. Detachment stress was found to be lower than ejection stress in the case of admixtures with Fujicalin ${ }^{\circledR}$. The relatively high ejection stress indicates that the addition of lubricant may be needed, with the exception of admixtures with $\mathrm{R}=10$ compressed at lower compression pressures.

The results obtained revealed superior properties of Fujicalin ${ }^{\circledR}$ as a carrier for LS systems, enabling higher liquid loads (up to 24.7\%) and better flow and compaction properties than MCC. Dynamic compaction analysis was shown to be a valuable tool for the assessment of compaction behavior of LS systems. The previously proposed value of pactisity greater than or equal to $20 \mathrm{~kg} / \mathrm{g}$ as a limiting value for compressible liquid load factor should be reconsidered in the case of novel highly porous excipients such as Fujicalin $^{\circledR}$, considering that all the investigated formulations with this carrier showed pactisity lower than $20 \mathrm{~kg} / \mathrm{g}$, and yet were found to have better compaction properties at higher liquid content than those with MCC.

\section{Acknowledgements}

This research was funded by the Ministry of Education, Science and Technological Development, Republic of Serbia through Grant Agreement with the University of Belgrade - Faculty of Pharmacy [No: 451-03-9/2021-14/200161].

\section{References}

1. Spireas S, Bolton SM. Liquisolid systems and methods for preparing same. United States patent 5,800,834, 1998.

2. Spireas S. Liquisolid systems and methods for preparing same. United States patent 6,423,339 B1, 2002. 
3. De Espíndola B, Beringhs AOR, Sonaglio D, Stulzer HK, Silva MAS, Ferraz HG, Pezzini BR. Liquisolid pellets: A pharmaceutical technology strategy to improve the dissolution rate of ritonavir. Saudi Pharmaceutical Journal. 2019;27(5):702-712.

4. Barmpalexis P, Grypioti A, Eleftheriadis GK, Fatouros DG. Development of a new aprepitant liquisolid formulation with the aid of artificial neural networks and genetic programming. AAPS PharmSciTech. 2018;19(2):741-752.

5. Elkadi S, Elsamaligy S, Al-Suwayeh S, Mahmoud H. The development of self-nanoemulsifying liquisolid tablets to improve the dissolution of simvastatin. AAPS PharmSciTech. 2017;18(7):2586-2597.

6. Pezzini BR, Beringhs AO, Ferraz HG, Silva MAS, Stulzer HK, Sonaglio D. Liquisolid technology applied to pellets: Evaluation of the feasibility and dissolution performance using felodipine as a model drug. Chem Eng Res Des. 2016;110:62-9.

7. Gong W, Wang Y, Sun L, Yang J, Shan L, Yang M, Gao C. Development of itraconazole liquisolid compact: Effect of polyvinylpyrrolidone on the dissolution properties. Curr Drug Deliv. 2016;13(3):452-461.

8. Hentzschel CM, Alnaief M, Smirnova I, Sakmann A, Leopold CS. Enhancement of griseofulvin release from liquisolid compacts. Eur J Pharm Biopharm. 2012;80:130-5.

9. Jhaveri M, Nair AB, Shah J, Jacob S, Patel V, Mehta T. Improvement of oral bioavailability of carvedilol by liquisolid compact: optimization and pharmacokinetic study. Drug Delivery and Translational Research. 2020;10(4):975-985.

10. Sheta NM, Elfeky YA, Boshra SA. Cardioprotective efficacy of silymarin liquisolid in isoproterenol prompted myocardial infarction in rats. AAPS PharmSciTech. 2020;21:81.

11. Patel K, Doddapaneni R, Patki M, Sekar V, Bagde A, Singh M. Erlotinib-valproic acid liquisolid formulation: evaluating oral bioavailability and cytotoxicity in erlotinib-resistant non-small cell lung cancer cells. AAPS PharmSciTech. 2019;20:135.

12. Jyoti J, Anandhakrishnan NK, Singh SK, Kumar B, Gulati M, Gowthamarajan K, et. al. A threepronged formulation approach to improve oral bioavailability and therapeutic efficacy of two lipophilic drugs with gastric lability. Drug Deliv and Transl Res. 2019;9:848-865.

13. Bonthagarala B, Dasari V, Kotra V, Swain S, Beg S. Quality-by-Design based development and characterization of pioglitazone loaded liquisolid compact tablets with improved biopharmaceutical attributes. J Drug Deliv Sci Technol. 2019;51: 345-355.

14. Khames A. Investigation of the effect of solubility increase at the main absorption site on bioavailability of BCS class II drug (risperidone) using liquisolid technique. Drug Deliv. 2017;24(1):328-338.

15. Khames A. Formulation and characterization of eplerenone nanoemulsion liquisolids, an oral delivery system with higher release rate and improved bioavailability. Pharmaceutics. 2019;11(1):40.

16. Nokhodchi A, Hentzschel CM, Leopold CS. Drug release from liquisolid systems: speed it up, slow it down. Expert Opinion on Drug Delivery. 2011;8(2):191-205.

17. Spireas S, Jarowski C, Rohera B. Powdered solution technology: principles and mechanism. Pharm Res. 1992;9(10):1351-8.

18. Vranikova B, Gajdziok J, Vetchy D. Determination of flowable liquid retention potential of aluminometasilicate carrier for liquisolid systems preparation. Pharm Dev Technol. 2015;20:839-844. 
19. Vranikova B, Gajdziok J. Evaluation of sorptive properties of various carriers and coating materials for liquisolid systems. Acta Ploniae Pharmaceutica - Drug Research. 2015;72(3):539-549.

20. Komala DR, Janga KY, Jukanti R, Bandary S. Competence of raloxifene hydrochloride loaded liquisolid compacts for improved dissolution and intestinal permeation. J Drug Deliv Sci Technol. 2015;30:232-241.

21. Anzilaggo D, Beringhs AO, Pezzini BR, Sonaglioa D, Stulzera HK. Liquisolid systems: Understanding the impact of drug state (solution or dispersion), nonvolatile solvent and coating material on simvastatin apparent aqueous solubility and flowability. Colloids Surf B Biointerfaces. 2019;175:36-43.

22. Badawy MA, Kamel AO, Sammour OA. Use of biorelevant media for assessment of a poorly soluble weakly basic drug in the form of liquisolid compacts: in vitro and in vivo study. Drug Delivery. 2016;23(3):818-827.

23. Kurek M, Woyna-Orlewicz K, Khalid MH, Jachowicz R. Optimization of furosemide liquisolid tablets preparation process leading to their mass and size reduction. Acta Poloniae Pharmaceutica Drug Research. 2016;73(5):1325-1331.

24. Lu M, Xing H, Yang T, Yu J, Yang Z, Sun Y, Ding P. Dissolution enhancement of tadalafil by liquisolid technique. Pharm Dev Technol. 2017;22:77-89.

25. Jaipakdee N, Limpongsa E, Sripanidkulchai B, Piyachaturawat P. Preparation of Curcuma comosa tablets using liquisolid techniques: In vitro and in vivo evaluation. Int J Pharm. 2018;553:157-168.

26. Jadhav NR, Irny PV, Patil US. Solid state behavior of progesterone and its release from Neusilin US2 based liquisolid compacts. J Drug Deliv Sci Technol. 2017;38: 97-106.

27. Aleksić I, German Ilić I, Cvijić S, Parojčić J. An Investigation into the Influence of Process Parameters and Formulation Variables on Compaction Properties of Liquisolid Systems. AAPS PharmSciTech. 2020;21(7):242.

28. Fuji Chemical Industry Co., Ltd., Brochure: The unique DCPA Fujicalin ${ }^{\circledR}$; 22021 [cited 2021 Feb 20]. Available from: http://www.fujichemical.co.jp/english/medical/medicine/fujicalin/index.html

29. Fell JT, Newton JM. Determination of tablet strength by the diametral-compression test. J Pharm Sci. 1970;59:688-691.

30. Armstrong NA, Haines-Nutt RF. Elastic recovery and surface area changes in compacted powder systems. J Pharm Pharmacol. 1972;24:135-136.

31. Hentzschel CM, Sakmann A, Leopold CS. Suitability of various excipients as carrier and coating materials for liquisolid compacts. Drug Dev Ind Pharm. 2011; 37(10):1200-1207.

32. European Pharmacopoeia 10th edition, Strasbourg: Council of Europe; 2019.

33. Thoorens G, Krier F, Leclercq B, Carlin B, Evrard B. Microcrystalline cellulose, a direct compression binder in a quality by design environment—A review. Int J Pharm. 2014;473:64-72.

34. McCormick D. Evolutions in direct compression. Pharmaceutical Technology. 2005;17(4):52-62.

35. Ragnarsson G. Force-displacement and network measurements. In: Alderborn G, Nystrom C, editors. Pharmaceutical Powder Compaction Technology. New York: Marcel Dekker In; 1996; p. 77-97.

36. Pitt KG, Webber RJ, Hill KA, Dey D, Gamlen MJ. Compression prediction accuracy from small scale compaction studies to production presses. Powder Technology. 2015;270:490-3. 


\title{
Tečno-čvrsti sistemi: Ispitivanje uticaja faktora formulacije na optimalno opterećenje tečnošču
}

\author{
Ivana Aleksić", Teodora Glišić, Sandra Cvijić, Jelena Parojčić \\ Univerzitet u Beogradu - Farmaceutski fakultet, Katedra za farmaceutsku tehnologiju i \\ kozmetologiju, Vojvode Stepe 450, 11221 Beograd, Srbija
}

*Autor za korespondenciju: Ivana Aleksić, e-mail: ivana.aleksic@pharmacy.bg.ac.rs

\section{Kratak sadržaj}

Tečno-čvrsti sistemi predstavljaju novi pristup izradi čvrstih farmaceutskih oblika koji sadrže tečnu lipofilnu lekovitu supstancu ili rastvor/suspenziju slabo rastvorljive lekovite supstance u pogodnom vehikulumu. Imajući u vidu nedostatak literaturnih podataka o ponašanju tečno-čvrstih sistema pri kompresiji, cilj ovog istraživanja je ispitivanje uticaja opterećenja tečnošću, odnosa nosača i sredstva za oblaganje, kao i vrste nosača (mikrokristalna celuloza i bezvodni kalcijum-hidrogenfosfat sušen raspršivanjem $\left(\right.$ Fujicalin $\left.^{\circledR}\right)$ ) na protočnost i svojstva tečno-čvrstih sistema pri kompresiji, kao i određivanje optimalnog opterećenja tečnošću. Tečnočvrste smeše sa Fujicalin ${ }^{\circledR}$-om su pokazale znatno bolju protočnost nego smeše sa mikrokristalnom celulozom. Uočeno je da se sa povećanjem odnosa nosača i sredstva za oblaganje poboljšava protočnost smeša. Kompakti sa Fujicalin ${ }^{\circledR}$-om su imali dobra mehanička svojstva do udela od 24,7\% tečnosti, a kompakti sa mikrokristalnom celulozom do udela od 16,2\% tečnosti. Tečno-čvrsti sistemi sa Fujicalin ${ }^{\circledR}$-om su pokazali slične profile tabletabilnosti onim sa mikrokristalnom celulozom, uprkos tome što sadrže znatno veći udeo tečnosti. Vrednosti pritiska potrebnog za izbacivanje kompakta iz matrice ukazuju da bi dodatak lubrikansa mogao biti potreban u slučaju tečno-čvrstih sistema sa Fujicalin ${ }^{\circledR}$-om. Dobijeni rezultati ukazuju na superiorna svojstva Fujicalin ${ }^{\circledR}$-a kao nosača u tečno-čvrstim tabletama, a dinamička analiza kompakcije može predstavljati koristan alat za procenu ponašanja tečno-čvrstih sistema pri kompresiji.

Ključne reči: tečno-čvrsti kompakti, tabletabilnost, dinamička analiza kompakcije,

Fujicalin ${ }^{\circledR}$, mikrokristalna celuloza 